\title{
誘導結合プラズマ質量分析法による 環境試料中のウランの定量
}

\author{
小倉 光夫 \\ 神奈川県環境科学センター（テ254-0072 神奈川県平塚市中原下宿842）
}

[平成11年 9 月 20 日受理］

\section{Determination of Uranium in Environmental Samples by Inductively Coupled Plasma Mass Spectrometry}

\author{
Mitsuo OGURA \\ Kanagawa Environmental Research Center \\ (842 Nakaharashimoshuku, Hiratsuka, Kanagawa 254-0072)
}

[Received September 20, 1999]

\begin{abstract}
Summary
An analytical condition of ICP-MS has been developed for accurate and rapid determination of uranium in environmental samples. The sample was digested with $\mathrm{HF} / \mathrm{HNO}_{3} / \mathrm{HClO}_{4}$, then uranium was determined by internal standardization method to compensate for non-spectroscopic interferences arising from matrix elements in the sample solution. Platinum was found to be effective as an internal standard.

Analytical results of 10 certified reference materials showed good agreement with the certified or reference values. The precision for the determination of uranium (relative standard deviation at 5 determinations) was $1.3 \sim 2.2 \%$ when Buffalo River Sediment and SL-1 were analyzed.

Uranium was detected in the range from 0.28 to $1.9 \mu \mathrm{g} / \mathrm{g}$ in sediments, 0.80 to $6.5 \mu \mathrm{g} / \mathrm{g}$ in sewage sludge, fly ash and suspended particulates, 0.004 to $0.068 \mu \mathrm{g} / \ell$ in river and spring water, and $2.6 \mu \mathrm{g} / \ell$ in seawater.

The determination limit $(10 \sigma)$ was $0.004 \mu \mathrm{g} / \ell$ in solution or $0.004 \mu \mathrm{g} / \mathrm{g}$ in environmental samples.
\end{abstract}

Key words: Uranium determination, ICP-MS, sediment, rock, environmental samples, internal standardization

\section{1.はじめに}

WHO（世界保健機関）では，ラットを用いた毒性試 験で腎障害が認められたとして，1998年ウラン（U）に ついて, 飲料水水質ガイドラインとして $0.002 \mathrm{mg} / \ell$ の暫 定值を定めた。これを受けて厚生省も同年 6 月「水道水
質に関する基準の制定について」の一部改正 ${ }^{1)}$ を行い, 亜硝酸性窒素とともにウランについて監視項目として新 たに追加し，その指針值は $0.002 \mathrm{mg} / \ell$ と設定した。

ウランは腎臓に蓄積されやすく, ヒトや動物に腎障害 をおこす ${ }^{2)}$ 。また, ウランは水銀と似た強い毒性をもち, 肝臓障害および腎臓障害, 胃炎を引き起こすと言われて 
いる ${ }^{3)}$ 。

ウランは原子カプラントの核燃料のほか, 陶磁器の黒 色うわ薬 (八酸化三ウラン)，ガラスの着色剂 (二ウラ ン酸ナトリウム), 写真, 分析用 (硝酸ウラニル) の用 途 ${ }^{3,4)}$ がある。

ウランの分析方法として, 吸光光度法, 固体蛍光法, $\alpha$ ースペクトロメトリー法 ${ }^{5}$, ICP 質量分析法 (ICP-MS 法) ${ }^{1,6-10)}$ などが報告されている。このうち, ICP-MS 法 は前記水道水質基準の測定法にも取り入れられており， その概要は硝酸酸性の試料水にタリウムを内標準元素と して加えて加熱分解後, ICP-MS 法で, ${ }^{238} \mathrm{U}$ と ${ }^{205} \mathrm{Tl}$ のイ オン強度からウランを定量することとなっている。しか し，タリウムを内標準とするこの方法を環境試料全般に 適用することは, タリウムが底質中に0.24 0.47 $\mu \mathrm{g} / \mathrm{g}$, 粉じんや污泥中には $1.2 \sim 1.9 \mu \mathrm{g} / \mathrm{g}$ と比較的高濃度で含ま れていることから ${ }^{11)}$ ，不適当である。

ここでは，極めて高感度で迅速な分析方法である ICP-MS 法を, 幅広い環境試料（淡水，海水や底質，岩 石，污泥などの固体試料）中のウラン定量に適用するた め, 適切な内標準元素の選定, 試料の調製方法など, 分 析条件を検討した。

\section{2. 実験}

\section{1 試薬}

$\mathrm{U}$ 標準溶液 $(10 \mathrm{mg} / \ell)$ は, Specx 社製 $(\mathrm{CL}-\mathrm{ICS}-4)$ を用いた。なお, 本標準溶液はUの他Mo, Th 各 $10 \mathrm{mg} / \ell$ を含む $2 \%$ 硝酸溶液となっている。 $\mathrm{Pt}(1,000 \mathrm{mg} / \ell)$ 及 び Bi $(1,000 \mathrm{mg} / \ell)$ 標準溶液は, 和光純薬製原子吸光分 析用試薬を用いた。硝酸, 塩酸, 過塩素酸, 硫酸は有害
金属測定用を，その他の試薬は特級規格品を用いた。り ん酸トリーn-ブチルは東京化成工業製, シクロヘキサン は和光純薬製精密分析用試薬を用いた。水はバーンス テッド社製 Nanopure 水を用いた。

\section{2 . 2 装置と測定条件}

ICP 質量分析装置は, 横河アナリティカルシステムズ 社製 HP4500を用いた。測定条件を Table 1に示した。 試料溶液のプラズマへの導入はペリスタルティックポン プを用いて行い,ネブライザーはバビントン型を用いた。

Table 1 Operating conditions

\begin{tabular}{ll} 
RF power & $1.5 \mathrm{Kw}$ \\
Plasma gas flow & $151 / \mathrm{min}$ \\
Carrier gas flow & $1.41 / \mathrm{min}$ \\
Sampling depth & $6 \mathrm{~mm}$ \\
Sample uptake rate & $0.35 \mathrm{ml} / \mathrm{min}$ \\
Measurement point & $3 \mathrm{points} / \mathrm{peak}$ \\
Integration time & $1.0 \mathrm{sec} / \mathrm{point}$ \\
Mass number & U238,Pt195(Bi209) \\
\hline
\end{tabular}

\section{3 試料}

環境標準試料は $105 \sim 110^{\circ} \mathrm{C}$ で 3 時間乾燥し, デシケー 夕中に保存した。実環境試料として, 河川水, 湧水, 海 水, 底質, 污泥, 飛灰及び浮遊粉じんを用いた。これら の採取地点の一部を Fig. 1に示した。水質試料は, 1998 年 8 月〜 12月に採取し，速やかに分析した。底質は1998 年 7 〜 10月に採取し，小石や異物を取り除いた後，乃紙 上に広げて時々かき混ぜながら約 18 時間風乾して水分を

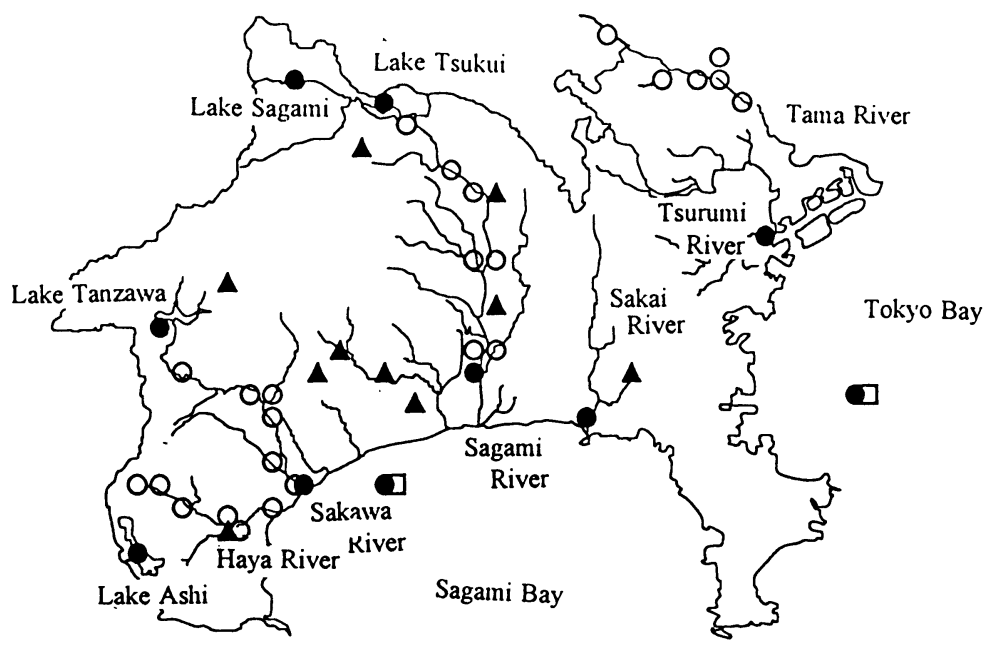

Fig. 1 Location of sampling sites

$\bigcirc$ river water $\boldsymbol{\Delta}$ spring water
$\square$ seawater $\quad$ sediment


除去した。これを $105 \sim 110^{\circ} \mathrm{C} て ゙ 3$ 時間乾燥後めのう製乳 鉢で細かく粉砕し,デシケータ中に保存した。飛灰は $\mathrm{A}$ 市清掃事業所, 下水污泥は B 流域下水処理場で採取し た。これらの試料は底質と同様の処理を行った。浮遊粉 じんは平塚市内(当センター屋上)でハイボリウムエアー サンプラーに石英繊維ろ紙（パルフレックス社製）を装 着し, 約 $1 \mathrm{~m}^{3} / \mathrm{min}$ の吸引速度で24時間採取した。

\section{4 固体試料の分解}

試料の分解方法として, 全量分解法と一般的に底質な ど環境試料の分解に用いられている混酸による抽出法と して底質調査方法 ${ }^{12)} に$ 準じた方法を用いた。

\section{4. 1 硝酸/過塩素酸/ふっ化水素酸分解 (A法)}

試料 $0.25 \mathrm{~g}$ をテフロンビーカーに量り取り，また浮遊 粉じん試料はろ紙の $1 / 2$ を切り取り, 硝酸 $10 \mathrm{~m} \ell$ と水少 量を加えて加熱分解後, 硝酸 $5 \mathrm{~m} \ell$ と過塩素酸 $1 \mathrm{~m} \ell$ を 加えて加熱を続け, 徐々に温度を上げ, 白煙を発生させ た。次いでふっ化水素酸 $10 \mathrm{~m} \ell$ を加えて加熱分解した。 更にふっ化水素酸 $2 \mathrm{~m} \ell$ を加えて加熱し, ほとんど蒸発 乾固した。これに $1 \mathrm{M}$ 硝酸 $5 \mathrm{~m} \ell$ と水約 $20 \mathrm{~m} \ell$ を加えて 1 時間加熱溶解し，水ですすぎ $50 \mathrm{~m} \ell$ 定容とした。

\section{4. 2 硝酸/塩酸/過塩素酸分解 (B 法)}

試料 $1 \mathrm{~g}$ をビーカーに量り取り, 硝酸 $10 \mathrm{~m} \cdot \ell$ と塩酸 20 $\mathrm{m} \ell$ と少量の水を加えて砂浴上で 2 時間加熱分解後, 硝 酸 $10 \mathrm{~m} \ell$ を加えて更に 1 時間加熱を続けた。これをろ紙 5 種 B でろ過し，ビーカー内及びろ紙を $0.1 \mathrm{M}$ 硝酸です すいだ。これらのろ洗液を砂浴上で約 $10 \mathrm{~m} \ell$ になるまで 濃縮後, 過塩素酸 $1 \mathrm{~m} \ell$ を加えて加熱分解し, 温度を上 げ白煙を発生させ, ほとんど蒸発乾固した。これに $1 \mathrm{M}$ 硝酸 $5 \mathrm{~m} \ell$ と過酸化水素水 $3 \mathrm{~m} \ell$, 水約 $20 \mathrm{~m} \ell$ を加えて 1 時間加熱溶解し，水ですすぎ $50 \mathrm{~m} \ell$ 定容とした。

\section{5 水質試料の試涻溶液の調製}

ICP-MS 装置への導入のし易さから, 想定される塩濃 度によって, 試料に応じて次の 2 種類の調製方法を用い た。

\section{（a）河川水及び涌水}

試料を良く振り混ぜ $20 \mathrm{~m} \ell$ を分取し， $1 \mathrm{M}$ 硝酸 $2 \mathrm{~m} \ell$ を 加えて静かに煮沸分解し, 放冷後, 水を加えて $20 \mathrm{~m} \ell$ 定 容とした。

\section{（b）海水}

試料 $10 \mathrm{~m} \ell$ を分液ロートに取り, 硝酸 $1 \mathrm{~m} \ell$ と硝酸ア ンモニウム $4.8 \mathrm{~g}^{13)}$ を加えて良く振り混ぜ， $10 \%(\mathrm{v} / \mathrm{v})$

りん酸トリ-n-ブチルシクロヘキサン溶液 $10 \mathrm{~m} \ell$ を加え て10分間振とうし，分離した。水層に10\%りん酸卜リ - $n$-ブチルシクロヘキサン溶液 $10 \mathrm{~m} \ell$ を加えて再び抽出
し, 溶媒層を別の分液ロートに合わせた。これに0.1M 塩酸 $10 \mathrm{~m} \ell$ を加えて Uを 2 回逆抽出した。 $0.1 \mathrm{M}$ 塩酸層 をビーカーに集め, 過塩素酸 $0.5 \mathrm{~m} \ell$ を加えて砂浴上（約 $160^{\circ} \mathrm{C}$ ）で加熱分解し，ほとんど蒸発乾固するまで濃縮 した。これに0.1M 硝酸 $10 \mathrm{~m} \ell$ を加えて, 30分間加熱溶解 し, 放冷後 $0.1 \mathrm{M}$ 硝酸ですすぎ, $20 \mathrm{~m} \ell$ 定容とした。

\section{6 定是操作}

2. $4,2.5$ で調製した試験溶液を $0.1 \mathrm{M}$ 硝酸溶液 となるように適宜希釈し, その $20 \mathrm{~m} \ell$ を分取し, $\mathrm{Pt}$ 溶液 $(100 \mu \mathrm{g} / \ell ， 0.1 \mathrm{M}$ 硝酸溶液） $1 \mathrm{~m} \ell$ を添加した。U 0〜 $10 \mu \mathrm{g} / \ell$ を含む標準溶液も同様に Pt 溶液 $(100 \mu \mathrm{g} / \ell)$ を加えた。これらの溶液を ICP-MS 装置でそれぞれのイ オン強度を測定し, U（測定質量数238）/Pt（測定質量 数195）の強度比から内標準添加検量線法で Uを定量し た。また比較のため, Bi を内標準とする方法及び検量 線（無補正）法でも定量した。

\section{3. 結果と考察}

\section{1 測定条件の検討}

ICP-MS 法での U 及び Pt 測定において，イオン強度 に大きく影響すると思われる高周波出力などについて検 討した。U 標準溶液 $(2.5 \mu \mathrm{g} / \ell)$ 及び環境標準試料 NIST2704（Buffalo River Sediment）から2.4A 法で調製 した試験溶液を 20 倍希釈 (U濃度約 $1.5 \mu \mathrm{g} / \ell$ ) したもの, それぞれを $20 \mathrm{~m} \ell$ 分取し, Pt 標準溶液 $(100 \mu \mathrm{g} / \ell)$ を $1 \mathrm{~m} \ell$ 添加した溶液に対し, 高周波出力を $1.0 \sim 1.5 \mathrm{Kw}$ に変化 させて, U及びPtのイオン強度を調べた。その結果を Fig. 2に示した。標準溶液では U 及び Ptとも $1.25 \mathrm{Kw}$ で イオン強度は最大となった。しかし, Buffalo River Sediment から調製した試験溶液では Pt は $1.25 \mathrm{Kw}$ で最大 となったが, Uのイオン強度は出力の増加と共に増大し た。この差異は, 標準溶液に比べ試験溶液中には高濃度 のマトリックスが含まれているため，Uのイオン化はよ り高いエネルギーが必要となるためと考えらた。ここで は高周波出力を, 各溶液とも安定したイオン強度が得ら れた $1.5 \mathrm{Kw}$ とすることとした。次に，キャリアーガス流 量 $(1.0 \sim 1.6 \ell / \mathrm{min}$.) 及びサンプリング位置 $(4 \sim 9 \mathrm{~mm})$ を変化させて検討したところ，両溶液とも $\mathrm{U}$ 及び $\mathrm{Pt}$ は $1.4 \ell / \mathrm{min} ., 6 \mathrm{~mm}$ で最大のイオン強度が得られた。これ らの結果から, ICP-MSの測定条件を Table1の通りとし た。

\section{2 酸湛度の影零}

ICP-MS 法での U 測定の際に共存する硝酸, 塩酸, 過 塩素酸及び硫酸の U イオン強度に与える影響について 検討した。U $5 \mu \mathrm{g} / \ell$ を含む硝酸0.05〜 1.5M溶液, 塩酸, 過塩素酸, 硫酸の $0.005 \sim 0.1 \mathrm{M}$ 溶液を個別に導入して U 
イオン強度を測定した（Fig. 3)。Uイオン強度は0.05 $0.25 \mathrm{M}$ 硝酸ではほほ一定で最大感度となったが, それ以 上の濃度では減少した。その他の 3 種の酸では， $0.025 \mathrm{M}$ 以下では影響は少ないが, $0.1 \mathrm{M}$ の共存では $10 \%$ 程度減 感した。従って, 2.4, 2.5での試料の分解, 調製で混酸 を使用する際は, ほとんど蒸発乾固して過塩素酸等を除

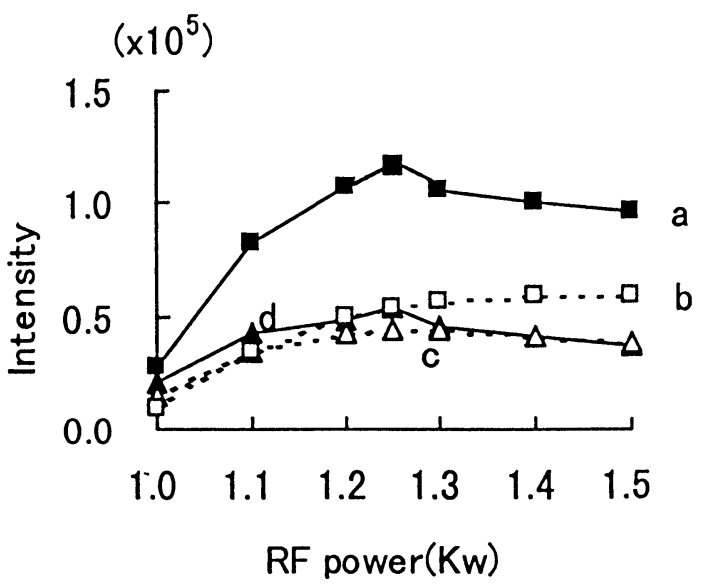

Fig. 2 Effect of RF power on the ion intensity of uranium and platinum

a,b: $\mathrm{U} \quad \mathrm{c}, \mathrm{d}: \mathrm{Pt}$

a,c $: 2.5 \mu \mathrm{g} / \ell$ U standard solution spiked 5 $\mu \mathrm{g} / \ell \mathrm{Pt}$

b,d: Diluted to twenty-fold of solution prepared from Buffalo River Sediment and spiked $5 \mu \mathrm{g} / \ell \mathrm{Pt}$ (carrier gas flow rate $1.41 / \mathrm{min}$., sampling depth $6 \mathrm{~mm}$ )

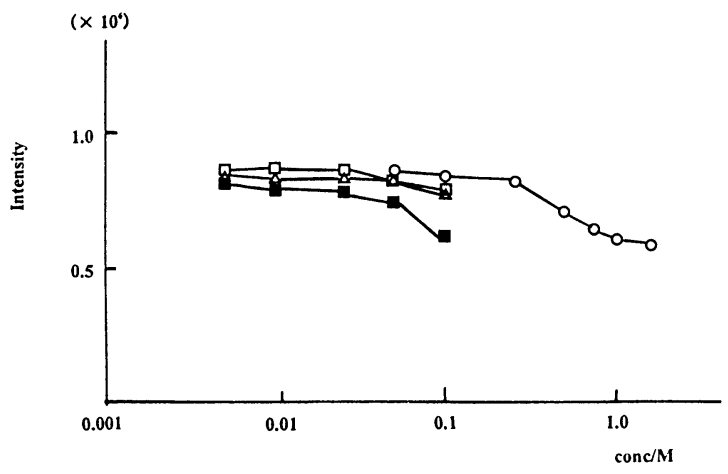

Fig. 3 Effect of acid concentration on the ion intensity of uranium (U5 $\mu \mathrm{g} / \ell$ )

$$
\begin{aligned}
& \bigcirc-\bigcirc \text { nitric acid } \\
& \square-\square \text { hydrochloric acid } \\
& \Delta-\triangle \text { perchloric acid } \\
& \square-\square \text { sulfuric acid }
\end{aligned}
$$

去し, 試験溶液は $0.1 \mathrm{M}$ 硝酸溶液とすることとした。

\section{3 内標準元素の選定}

ICP-MS 法による測定では, 共存するマトリックスに よって目的元素のイオン化が抑制される等信号強度が変 化するマトリックス効果を受けやすい（Table 2)。これ を補正するため, 内標準元素を添加し, マトリックス効 果による影響を相殺する方法が有効である。そこで, 適 切な内標準元素の選定を行うため, 後述 $(3.6,3.7 .1)$ の 固体試料中の U 分析に先立ってそれぞれの試験溶液を 適宜希釈して, 質量数170 240で定性分析を行った。一 般的に内標準元素として, 目的元素と質量数が近いこと, イオン化ポテンシャルが同等である, 試験溶液中に含ま れていないことが望ましいとされている。このため一般 に高質量側では Tl が用いられているが, 定性分析の結 果, Tl は U と同濃度レベルかそれ以上でいずれの試験 溶液からも検出された。環境試料中には $\mathrm{T} 1$ が底質中 $0.24 \sim 0.47 \mu \mathrm{g} / \mathrm{g}$, 浮遊粉じんや下水污泥中 $1.2 \sim 1.9 \mu \mathrm{g} / \mathrm{g}$

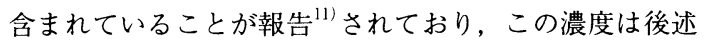
の環境試料中（固体試料）のU 濃度と同濃度レベルに 相当した。このことから, 前記水道水質基準の測定方法 に定められている Tl を内標準とする方法 ${ }^{1}$ は, 幅広い環 境試料に適用することは困難であることが明らかになっ た。そこで, 質量数の近さ及びイオン化ポテンシャルの 高さから，Bi を選定したが Fig. 4に一例（Pt，Bi，Uの みを抜粋）を示したように，一部の試験溶液から Uを 上回る高いイオン強度の Bi が検出される試料があるこ とが判明した。このように Bi が高い濃度で共存する試 料を, Bi を内標準元素としてU 分析を行うと過補正の 結果, U 分析值は低值となる (Table 2)。そこで, 各試 験溶液から低濃度でしか検出されなかった Ptを内標準 元素とすることとした。PtはICPにおけるイオン化率 が $62 \%$ と低い難点があるが, 前報 ${ }^{11}$ で示したように内標 準元素としての有効性が証明されている。

\section{4 質量スペクトル干渉}

ICP-MS 法で測定する際には，共存成分による分子イ オンや多原子イオンによる質量スペクトル干涉を考慮す る必要がある。この干渉は, 酸化物, 水素化物, 水酸化 物やアルゴン化物が問題となることが多い。 ${ }^{238} \mathrm{U}$ に干涉 すると考えられるのは ${ }^{198} \mathrm{Hg}^{40} \mathrm{Ar},{ }^{198} \mathrm{Pt}^{40} \mathrm{Ar},{ }^{203} \mathrm{Tl}{ }^{35} \mathrm{Cl}$ どである。そこで, これらの分子イオン生成による ${ }^{238} \mathrm{U}$ への影響を検討した。 $\mathrm{Hg}^{2+}$ 及び $\mathrm{Pt}^{4+}$ の10 1000 $\mu \mathrm{g} / \ell$ (0.1M 硝酸) 各標準溶液と $\mathrm{Tl}^{+}$の $10 \sim 1000 \mu \mathrm{g} / \ell \quad(0.1 \mathrm{M}$ の硝酸及び塩酸を含む) 標準溶液を個別に ICP-MS 装置 に導入し, ${ }^{238} \mathrm{U}$ のイオン強度を測定した。その結果, こ れらによる ${ }^{238} \mathrm{U}$ のイオン強度の増加は認められなかっ た。 


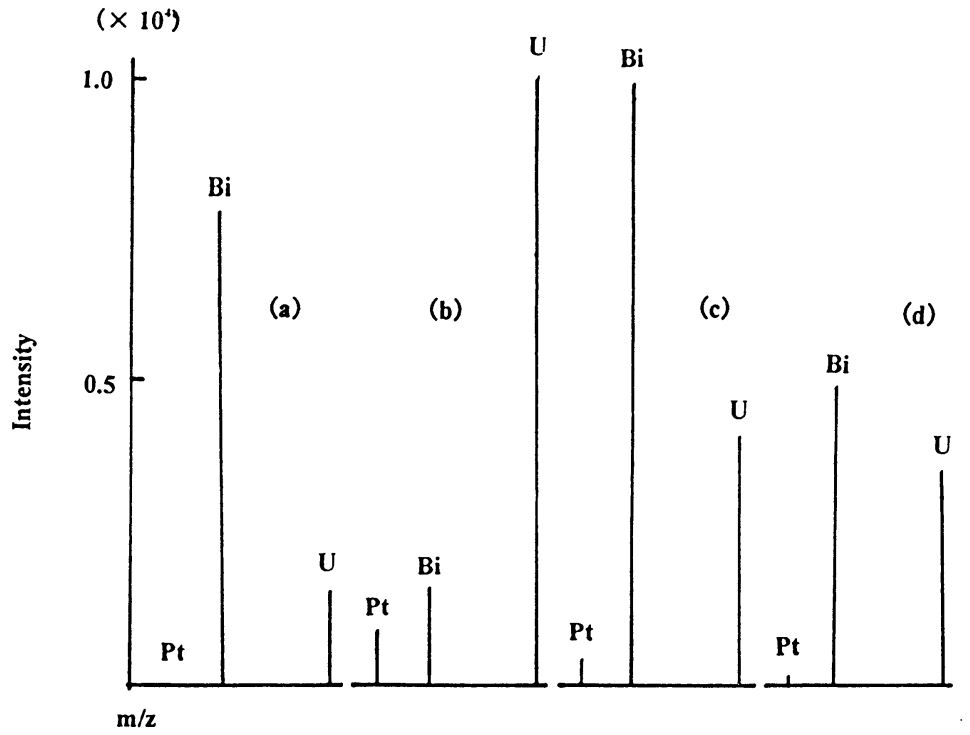

Fig. 4 ICP-MS spectrum of $\mathrm{Pt}, \mathrm{Bi}, \mathrm{U}$ in diluted (ten-fold) sample solutions

a: River Sediment (NIST1645)

b: Buffalo River Sediment(NIST2704)

c: sludge d: suspended paticulates

\section{5 海水試料からのU 抽出 / 逆抽出}

海水試料を直接 ICP-MS 装置に導入できないため, 海 水中のUを溶媒抽出後逆抽出する方法を検討した。U は硝酸溶液から，りん酸トリーn-ブチルの各種溶媒に抽 出されることが知られている ${ }^{13)}$ 。また, U は高濃度の硝 酸塩の共存下で, 含酸素有機溶媒に抽出される ${ }^{13)}$ 。更に 抽出された $\mathrm{U} は, 0.1 \mathrm{M}$ の塩酸で定量的に逆抽出される ことが報告されている ${ }^{10)}$ 。そこで，東京湾海水 $10 \mathrm{~m} \ell$ を 用いて 2.5 (b) 中の硝酸アンモニウム $4.8 \mathrm{~g}$ (約 $6 \mathrm{M} に$ に相当) 添加と無添加について, また同海水 $10 \mathrm{~m} \ell に U$ U $0.01 \mu \mathrm{g}$ 添加した場合について, 得られる分析值及び回収率を比 較した。その結果同海水中のU 濃度は, 硝酸アンモ二 ウムの有無にかかわらず $2.64 \mu \mathrm{g} / \ell$ となったが, 回収率 は添加 $96 \%$ ，無添加 $86 \%$ と差が見られたため，添加する こととした。なお，硝酸塩として硝酸ナトリウムも検討 したが, この場合逆抽出溶液中には高濃度のナトリウム の残留が認められ不適当であった。

この操作によって, 海水中の主要陽イオン ( $\mathrm{Na}, \mathrm{K}$, $\mathrm{Mg}$ ，Ca）はいずれも約 $98 \%$ が除去され，ICP-MS 装置に 導入する試験溶液中の残留濃度は Na 109, K 3.3, Mg 9.6, Ca $3.5 \mathrm{mg} / \ell$ であることをフレーム原子吸光法によって 確認した。

\section{6 標準試料の U 分析}

種々の環境標準試料のU 分析結果を Table 2 に示し た。表には, 本法 (Pt内標準法) の他, Bi 内標準法及
び検量線法 (無補正)による結果も比較のため表記した。 本法による底質 (河川, 湖沼), 岩石, 飛灰及び土壤か ら調製された 10 種の標準試料のU 分析值はいずれも保 証值，推薦值または参考值と良く一致した結果が得られ た。これに対し，Bi 内標準法によった場合 NIST1645 (River Sediment) では有意に低值となった。この原因 は3.3で示したように，試料中に高濃度で含まれていた Bi によって過補正が生じ，その結果低值となったもの と考えられる。検量線法でのU 分析値は, 本法及び保 証值等と比較して，いずれも 10 ３0％低值となり，マト リックス効果を強く受けており, 適切な内標準元素によ る補正が不可欠であることが明らかになった。

また, 5 回の全操作に亘る繰り返し分析精度はBuffalo River Sediment 1.3\%，SL-1 2.2\%と良好であった。更に Buffalo River Sediment $0.25 \mathrm{~g}$ にU $1 \mu \mathrm{g}$ を添加し回収率を 検討したところ, 平均 $96 \%(\mathrm{n}=2: 93,98 \%)$ が得られた。

\section{7 実環境試料の U 分析}

\section{7. 1 固体試料}

神奈川県内から採取した環境試料（固体）について, 2.4.1 (A 法) で分解し, 本法 (Pt 内標準法) で U 分析 を行った結果を Table 3に示した。表には 3.6 と同様, Bi 内標準法, 検量線法による結果及び2.4.2 (B 法) で分解 し，本法で分析した結果も併記した。U 分析值は，底質 では Bi 内標準法は本法とほほ同等の結果となったが, 飛灰, 下水污泥及び浮遊粉じんでは低值となった。これ 
Table 2 Analytical results of uranium in standard reference materials

\begin{tabular}{|c|c|c|c|c|}
\hline \multirow[t]{2}{*}{ Sample } & \multirow[t]{2}{*}{ Certified value } & \multicolumn{3}{|c|}{ Analytical value } \\
\hline & & proposed method & $\begin{array}{l}\mathrm{Bi} \text { internal } \\
\text { standardization }\end{array}$ & $\begin{array}{l}\text { calibration } \\
\text { method }\end{array}$ \\
\hline \multicolumn{5}{|l|}{ NIST" } \\
\hline $\begin{array}{l}\text { Buffalo River Sediment } \\
\text { (NIST2704) }\end{array}$ & & $3.05 \underset{(n=5)}{ \pm 0.04}$ & $\underset{(n=5)}{2.83 \pm 0.01}$ & $2.63 \underset{(n=5)}{ \pm 0.18}$ \\
\hline $\begin{array}{l}\text { River Sediment } \\
\text { (NIST1645) }\end{array}$ & $1.11 \pm 0.05$ & 1.12 & 0.650 & 0.806 \\
\hline $\begin{array}{l}\text { Coal fly ash } \\
\text { (NIST1633a) }\end{array}$ & 10.2 & 9.89 & 10.1 & 8.90 \\
\hline $\begin{array}{l}\text { Coal fly ash } \\
\text { (NIST1633b) }\end{array}$ & $8.79 \pm 0.36$ & 8.55 & 8.40 & 6.92 \\
\hline $\begin{array}{l}\text { San Joaquin Soil } \\
\text { (NIST2709) }\end{array}$ & (3)* & 2.76 & 2.74 & 2.27 \\
\hline \multicolumn{5}{|l|}{$G S J^{b}$} \\
\hline JA-3 (rock) & 1.18 & 1.00 & 1.07 & 0.741 \\
\hline JB-1 (rock) & 1.67 & 1.76 & 1.89 & 1.23 \\
\hline JG-1 (rock) & 3.47 & 3.18 & 3.14 & 2.51 \\
\hline JLK-1 (sediment) & 3.83 & 3.81 & 3.59 & 3.30 \\
\hline IAEA $^{c}$ SL-1 (sediment) & $4.02 \pm 0.32$ & $3.86 \underset{(\mathrm{n}=5)}{ \pm 0.08}$ & $\begin{array}{c}3.79 \pm 0.05 \\
(n=5)\end{array}$ & $\begin{array}{c}3.32 \pm 0.126 \\
(\mathrm{n}=5)\end{array}$ \\
\hline
\end{tabular}

' National Institute of Standard and Technology,U.S.A ' Geological Survey of Japan,Japan

' International Atomic Energy Agency,Austria

* Value is information only, and is not certified

Table 3 Determination of uranium in environmental samples

\begin{tabular}{|c|c|c|c|c|}
\hline \multirow[t]{2}{*}{ Sample } & \multicolumn{4}{|c|}{ Analytical value } \\
\hline & $\begin{array}{r}\text { proposed } \\
\text { (Pt internal sta } \\
\mathrm{A}^{*}\end{array}$ & $\begin{array}{l}\text { ethod } \\
\text { dardization) } \\
\mathrm{B}^{*}\end{array}$ & $\begin{array}{l}\text { Bi internal } \\
\text { standardization } \\
\mathrm{A}^{*}\end{array}$ & $\begin{array}{l}\text { calibration } \\
\text { method } \\
A^{*}\end{array}$ \\
\hline Sediment & 0.600 & 0.252 & 0.625 & 0.460 \\
\hline Sakawa river & 0.289 & 0.103 & 0.313 & 0.192 \\
\hline Sakai river & 0.523 & 0.226 & 0.560 & 0.378 \\
\hline lake Sagami & 1.17 & 0.495 & 1.17 & 0.858 \\
\hline lake Tsukui & 0.878 & 0.423 & 0.880 & 0.661 \\
\hline lake Ashi & 0.584 & 0.448 & 0.566 & 0.442 \\
\hline lake Tanzawa & 0.322 & 0.266 & 0.326 & 0.207 \\
\hline Tokyo bay & 0.822 & 0.496 & 0.862 & 0.617 \\
\hline Sagami bay & 0.295 & 0.149 & 0.309 & 0.228 \\
\hline mouth of Tsurumi river & 1.91 & 1.26 & 1.77 & 1.59 \\
\hline Fly ash & 0.802 & 0.674 & 0.416 & 0.549 \\
\hline Sewage sludge & 1.78 & 1.43 & 0.585 & 1.50 \\
\hline Suspended particulate & 6.57 & 0.333 & 4.98 & 5.91 \\
\hline
\end{tabular}

$\begin{aligned} \text { Digestion method } & { }^{*} \mathrm{~A} ; \mathrm{HNO}_{3} / \mathrm{HClO} / \mathrm{HF} \\ & { }^{*} \mathrm{~B} ; \mathrm{HNO} / \mathrm{HCl} / \mathrm{HClO} \text {, }\end{aligned}$ 
ら後者の試験溶液中には，3.3で述べたように，定性分 析の結果 Bi が高濃度で検出されていた。また, 検量線 法での分析值は標準試料の場合と同様に本法に比べ，10 $35 \%$ 低值となった。

底質中の U 濃度は $0.289 \sim 1.91 \mu \mathrm{g} / \mathrm{g}$ (平均 $0.739 \mu \mathrm{g} / \mathrm{g}$ ), 飛灰など他の環境試料では $0.802 \sim 6.57 \mu \mathrm{g} / \mathrm{g}$ で, 浮遊粉 じん中に高濃度で検出された。B 法によるU 分析值は, 全量分析值（A 法）と比べ, 浮遊粉じんでは $95 \%$ ，その 他試料でも約15～65\%低い值であった。

\section{7.2 環境水試料}

河川水（4 河川, 25地点) 中の $\mathrm{U}$ 濃度は, <0.004 $0.043 \mu \mathrm{g} / \ell$ で平均濃度は $0.018 \mu \mathrm{g} / \ell$ であった。また, 神 奈川名水百選に選ばれている10湓水中の U 濃度は, $0.007 \sim 0.068 \mu \mathrm{g} / \ell$, 平均 $0.027 \mu \mathrm{g} / \ell$ であった。これら河 川水, 湧水中の $\mathrm{U}$ 濃度分布はともに, $0.01 \mu \mathrm{g} / \ell$ 以下が 約 $20 \%, 0.01 \sim 0.02 \mu \mathrm{g} / \ell$ が約50\%であり，いずれも U 指針值 $0.002 \mathrm{mg} / \ell$ と比較して, 低濃度であった。

東京湾, 相模湾海水中の $\mathrm{U}$ 濃度は, それぞれ 2.64 , $2.78 \mu \mathrm{g} / \ell$ であった。また, 全操作に亘る 5 回の繰り返 し分析精度は $0.3 \%$ (東京湾海水) であった。

一般に, 海水中の U は陸水に比べ約100倍に濃集して いると言われているが(4), 今回の調查結果はそれと一致 するものであった。

本法の定量限界は空試験值の $10 \sigma$ から算出すると, 溶 液中 $0.004 \mu \mathrm{g} / \ell$ が得られ, 本研究で用いた標準的な測定 では, 試料 $0.25 \mathrm{~g}$ を分解し, $50 \mathrm{~m} \ell$ とした後 5 倍希釈した ため, 固体試料中 $0.004 \mu \mathrm{g} / \mathrm{g}$ に相当した。

\section{要 約}

ICP 質量分析法による環境試料中のウランの正確で迅 速な分析方法を検討した。試料を硝酸/過塩素酸/ふつ 化水素酸で分解し, 希硝酸に溶解して試験溶液とした。 マトリックス効果を補正するため, 白金を内標準元素と して用いた。本法による種々の環境標準試料のウラン分 析值は,いずれの試料でも保証值等と良く一致した。また, 繰り返し分析精度 $(\mathrm{n}=5)$ は, Buffalo River Sediment 及 びSL-1は，1.3〜2.2\%であった。本法のウランの定量限界 は溶液中 $0.004 \mu \mathrm{g} / \ell$, 試料中（固体） $0.004 \mu \mathrm{g} / \mathrm{g}$ であっ た。環境試料から $0.28 \sim 1.9 \mu \mathrm{g} / \mathrm{g}$ (底質), $0.80 \sim 6.5 \mu \mathrm{g} / \mathrm{g}$ (下水污泥, 飛灰, 浮遊粉じん), $0.004 \sim 0.068 \mu \mathrm{g} / \ell$ (河 川水, 湧水), $2.6 \mu \mathrm{g} / \ell$ (海水) のU が検出された。

\section{文 献}

1）厚生省「水道水質に関する基準の制定について」： 生衛発第928号 (1998)

2) 荒木 俊, 沼田 眞, 和田 攻編：環境科学辞典, $\mathrm{pp} 63$, 東京化学同人 (1985)

3）化学工業日報社編：13398の化学商品, pp199-200 (1998)

4) 馬淵久夫編集 : 元素の事典, pp269, 朝倉書店 (1994)

5）日本分析化学会編：分析化学便覧, pp307-311, 丸 善, (1991)

6) Igarashi, Y., Kawamura, H., Shiraishi, K. and Takaku Y.: Determination of Thorium and Uranium in Biological Samples by Inductively Coupled Plasma Mass Spectrometry Using Internal Standardisation. J. Anal. At. Spectrom., 4, 571-576 (1989)

7) Boomer, D.W. and Powell, M.J.: Determination of Uranium in Environmental Samples Using Inductively Coupled Plasma Mass Spectrometry. Anal. Chem. 59, 2810-2813 (1987)

8) Bailey, E.H., Kemp, A.J. and Ragnarsdottir, V.: Determination of Uranium and Thorium in Basalts and Uranium in Aqueous Solution by Inductively Coupled Plasma Mass Spectrometry. J. Anal. At. Spectrom., 8, 551-556 (1993)

9) McLaren, J.W., Beauchemin, D. and Berman, S.S.: Analysis of the marine sediment reference material PACS -1 by inductively coupled plasma mass spectrometry. Spectrochim. Acta, 43B, 413-420 (1988)

10) Takeda, K., Yamaguchi, T., Akiyama, H. and Masuda, T.: Determination of Ultra-trace Amounts of Uranium and Thorium in High-purity Aluminium by Inductively Coupled Plasma Mass Spectrometry. Analyst, 116, 501-504 (1991)

11）小倉光夫：誘導結合プラズマ質量分析法による環境 試料中の夕リウムの定量, 環境化学, 8, 781-786 (1998)

12）環境庁：底質調査方法 水質保全局長通達（昭和63 年環水管第127号）（1988）

13) Sandell, E.B.: Colorimetric Determination of Traces of Metals, pp903-904, Interscience, New York (1959)

14）工業技術院地質調査所編：地球科学的試料の化学分 析法 1, pp230 (1976) 